\author{
استفاده از نانو ذرات رس براى تثبيت خاكهاى رسى متورم شونده \\ آرش فرجاد' و نادر عباسى

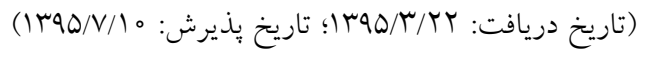

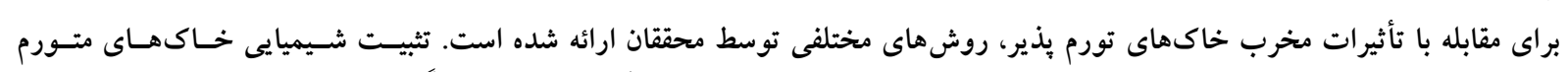

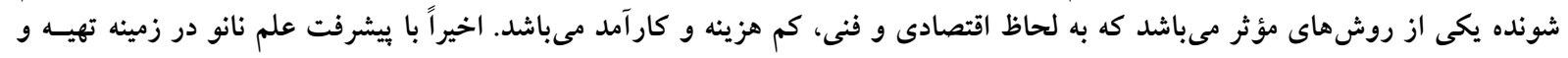

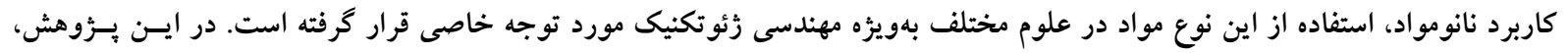

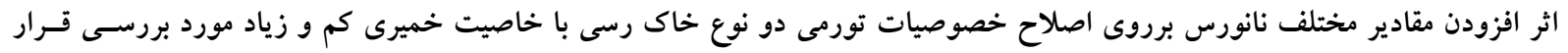

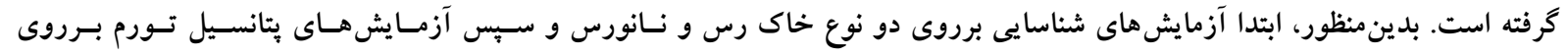

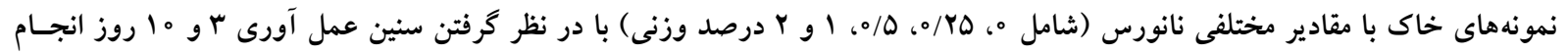

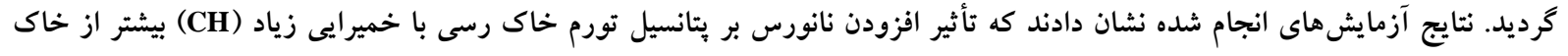

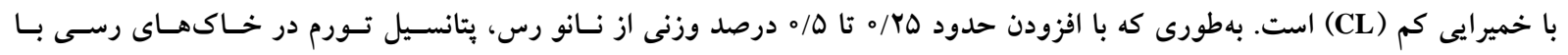

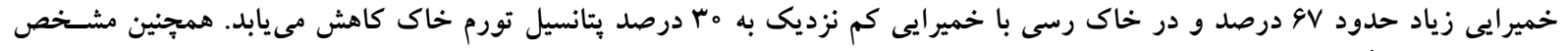

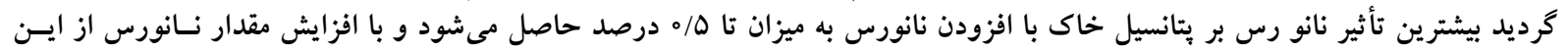

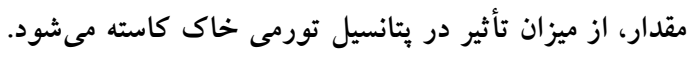

وازمهاى كليدى: يتانسيل تورم، تثبيت، فشار تورم، نانورس

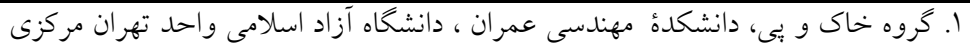

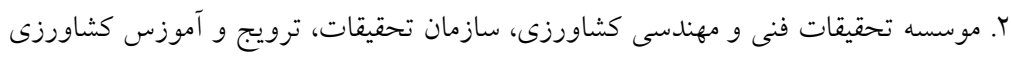

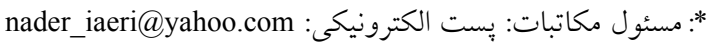


ييش مرطوب سازى، تعويض خاك محل اجراى يـروزه، تثبيـت

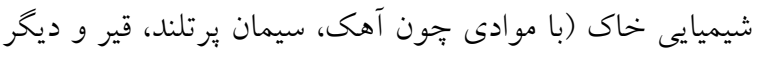

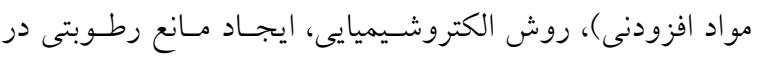

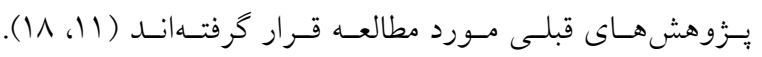

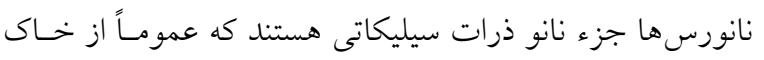

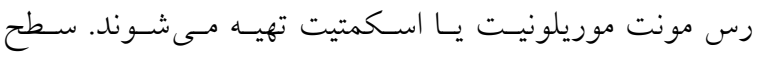

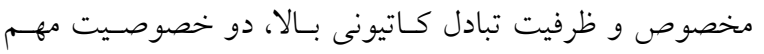

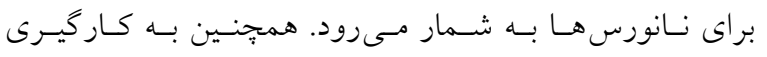

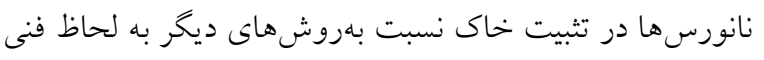

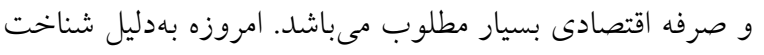

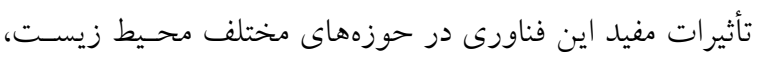

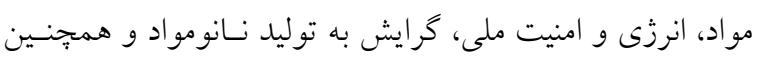

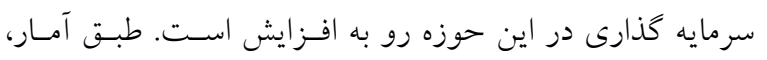

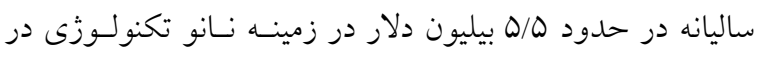

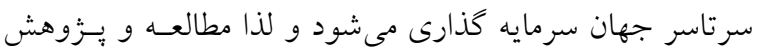
در اين زمينه مى تواند موجب توليد هدفمند محصولات نان انومواد

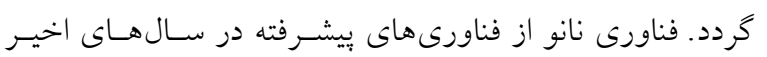
مىباشد كه حدود نيم قرن بيش به دنيـا معرفى شــد. از جملـه

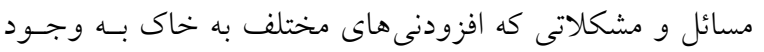

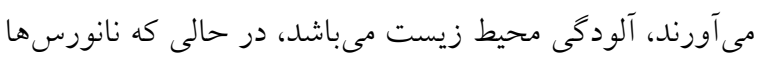

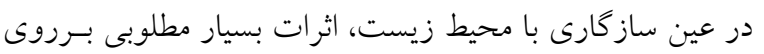

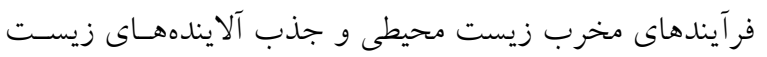
محيطى دارند (19).

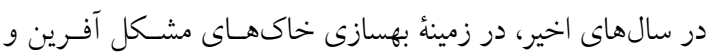

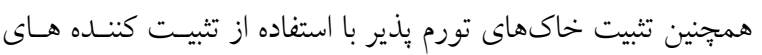
مدرن نظير مواد بليمرى، يزوهشهاى زيادى صورت گرفته است (rا،

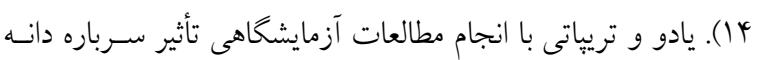

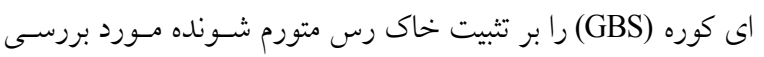

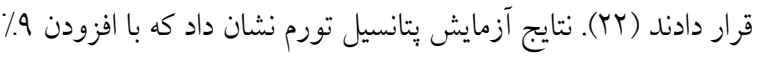

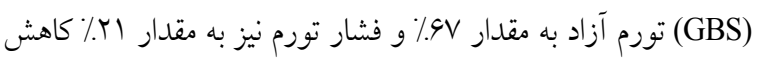

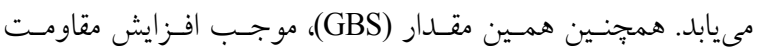

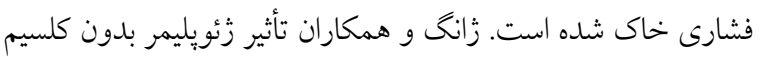

\section{مقلم مه}

خاك متورم شونده خاكى است كه در اثر تغييـر رطوبـت، دجــار

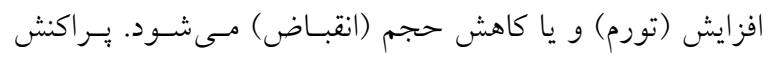

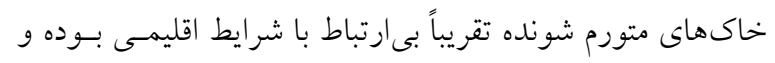

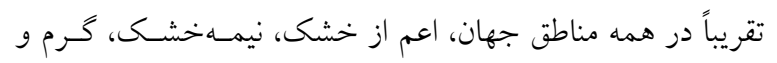

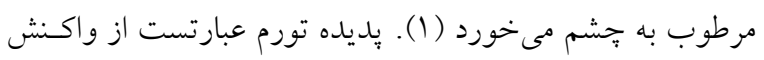

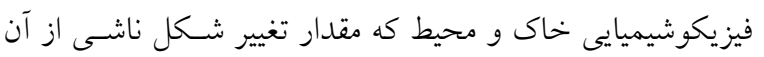
بستخى به شدت نيروهاى جاذبه و دافعه فيزيكى و شيميايى دارد

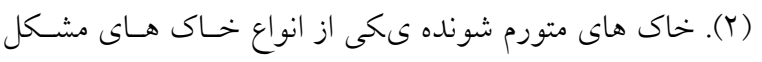

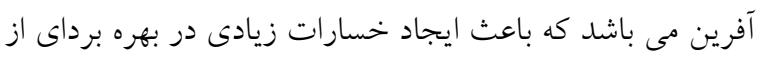

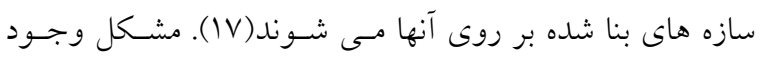

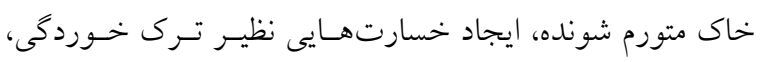

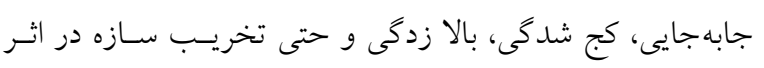

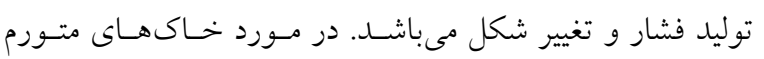
شونده و مشكلات ناشى از آن نيز مى توان به ايسن مطلـب اشــاره

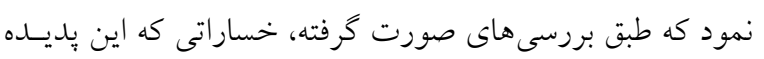

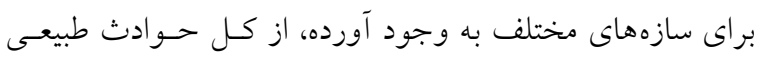

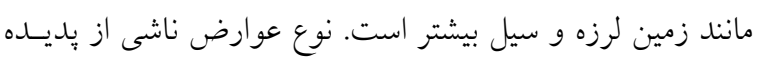

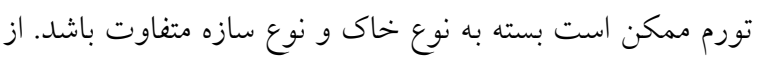

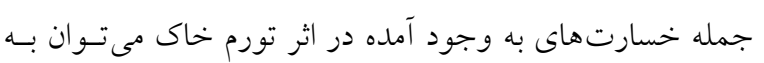
تركهاى قطرى در ديوار، جدا شدكى ديوار از كـف سـازه، كيــ

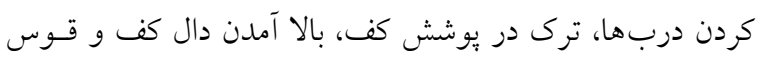

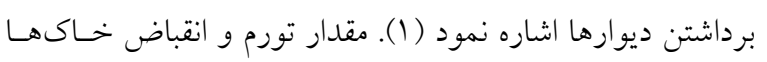

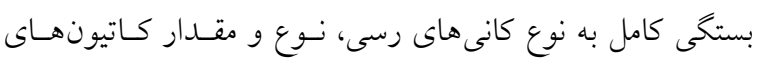

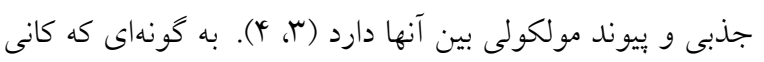

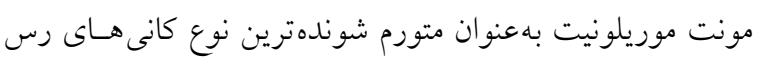

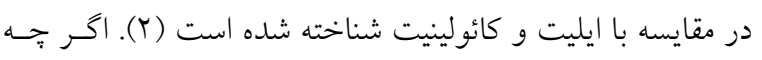

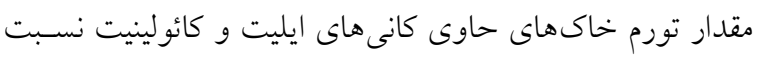

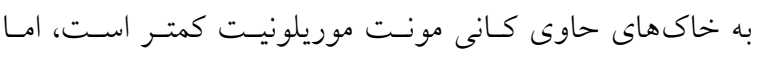

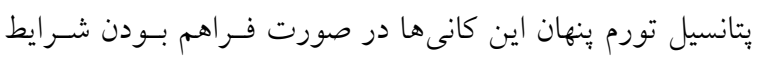

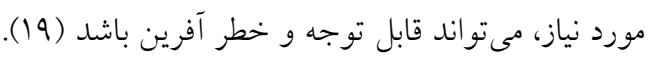
روش هاى معمول اصلاح خاكهاى متـورم شـونده از قبيـل 
بررسى اثـر نسانومواد بـر خصوصسيات زئسو تكنيكى خـاك ريزدانسه،

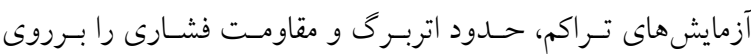

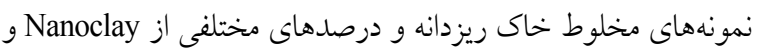
Nano MgO بيشترين تأثير مثبت بر مقاومت فشارى توسط نانورس به وجود آمــه

بررسى سوابق تحقيقات محققين بيشين در رابطه بـا تثبيـت

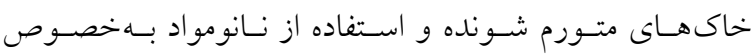

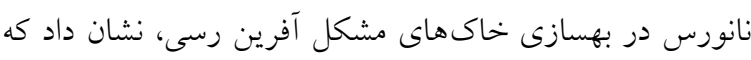

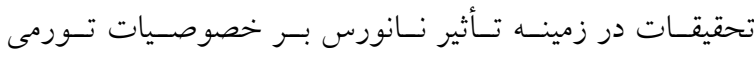
خاك هاى رسى با طبقهبندى مختلف محدود است. لذا، در ايسن يزوهش اثر افزودن مقادير مختلف نانورس برزوى خصوصسيات تورمى دو نوع خاك رس با بلاستيسيته كم (CL) و بِلاستيسيته

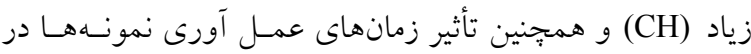
سنين مختلف مورد ارزيابى قرار كرفته است.

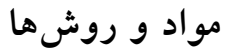 معرفى نمونه خاك}

براى انجام اين يزوهش، دو نمونه خاك از منطقه ايوانكى - شهر

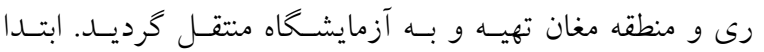

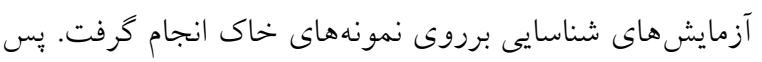

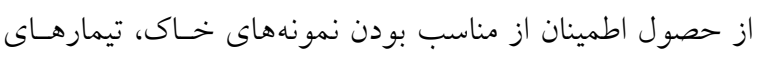

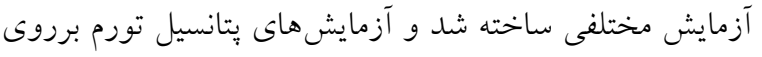

$$
\text { تيمارها انجام كرفت. }
$$

\section{آزمايشهاى شناسايى خاك}

آزمايش دانهبندى يكى از آزمايشهاى بايه دايه در مطالعات زئوتكنيك

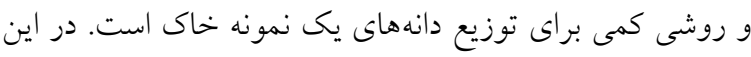

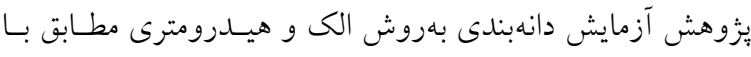

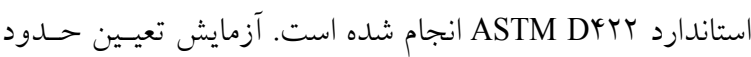

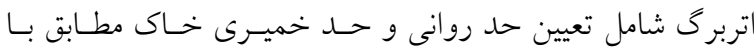

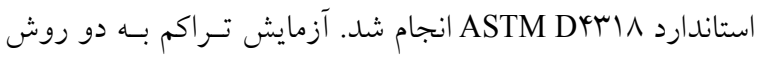

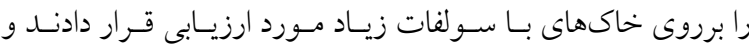

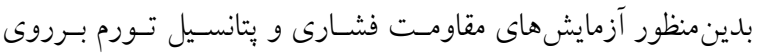

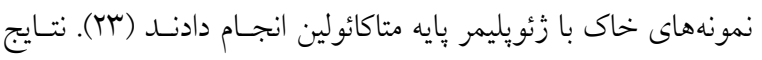

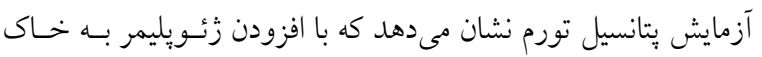

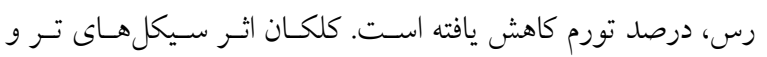
خشك شدكى بر رفتار تورمى خاكهاى رسى با خاصيت خميرى بالا (CH)

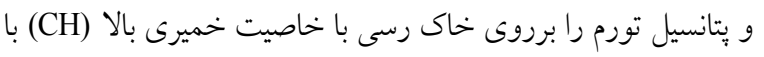

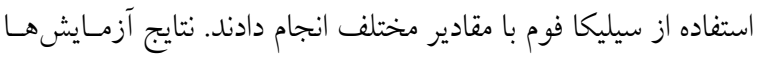

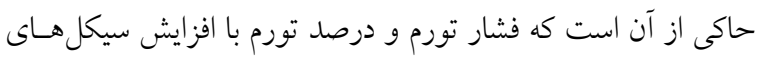
تر - خشك شدكى و همجنين افزايش درصد سيليكا فوم كاهش يافته أنه

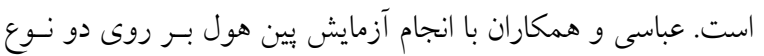

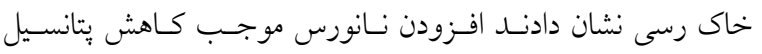

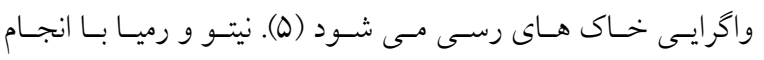

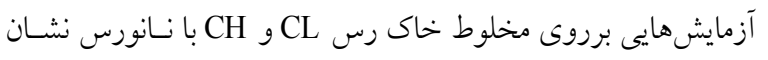
دادند كه افزايش نانورس باعث افزايش مقاومت فشارى تكى محورى مائ

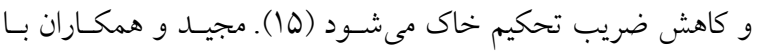

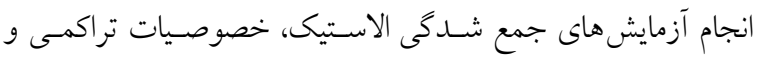
مقاومت فشارى محدود نشده برروى مخلوط خاك و نانو مواد نشـان دادند كه استفاده از نانورس در تثبيت خاكهـاى ريزدانهه در افزرايش

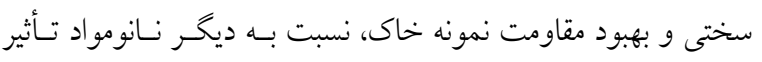

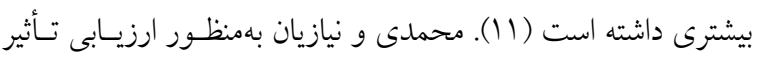
نانورس بر خصوصيات زئوتكنيكى خاك رس، آزمايشهـاى تـراكم،

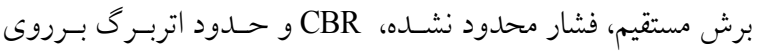
خاك رس CL و مخلوط شده با درصدهاى مختلـف نـانورس انجـام دادند و دريافتند كه مقاومت برشى، مقاومت فشارى و CBR خاك بـا افزايش درصد نانورس تا ه/1/، افزايش يافته و در درصد هاى بـالاتر

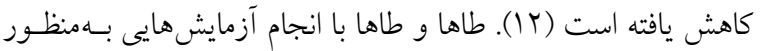

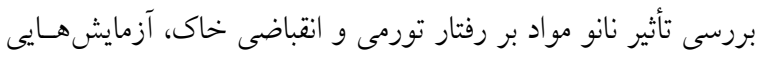

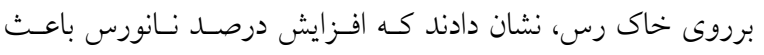
افزايش كرنشهاى تورمى و انقباضى و حجم كلى خاك شده است و

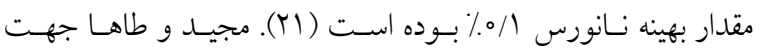




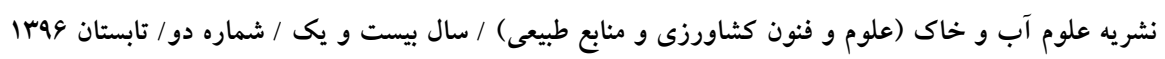

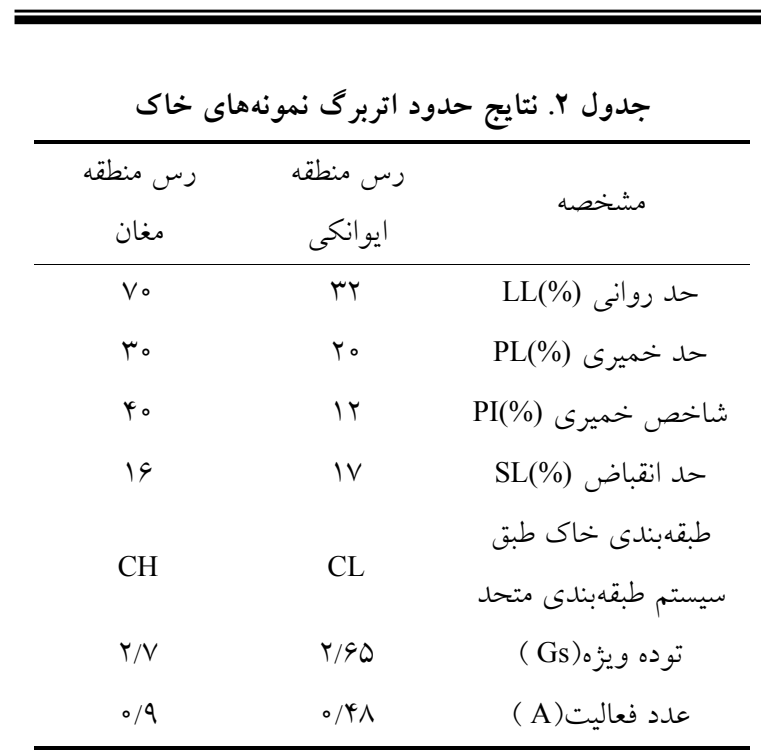

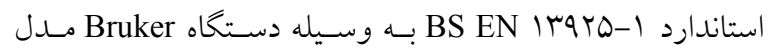
DY-Endeavor

$$
\begin{aligned}
& \text { (YTheta } \\
& \text { آزمايش تعيين يتانسيل تورم } \\
& \text { معرفى آزمايش بتانسيل تورم تعين بتاسيل تورم }
\end{aligned}
$$

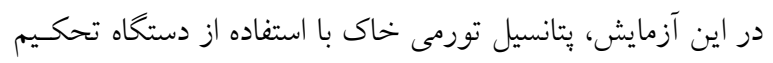

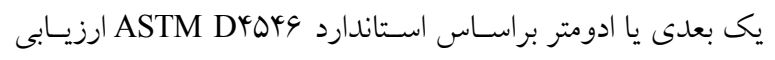

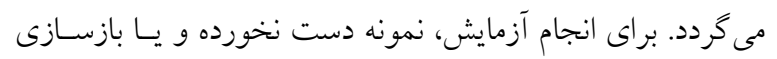

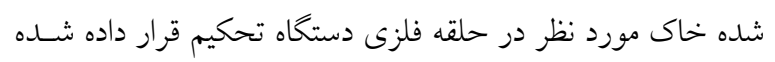
و آزمايش در يكى از سه حالت زير انجام مى گيرد:

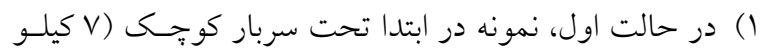

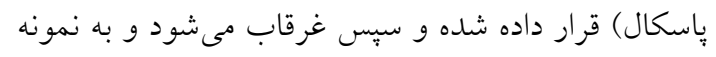

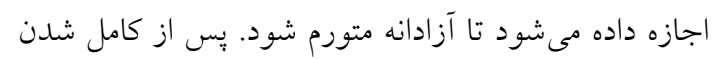

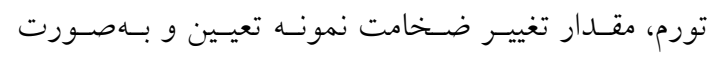

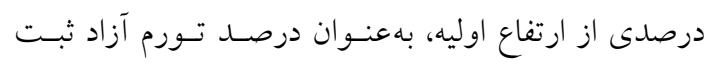

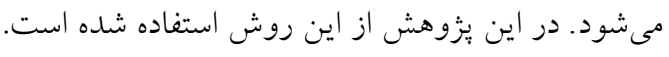

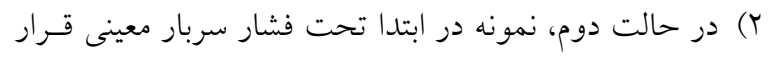

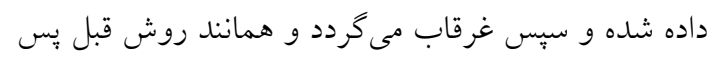

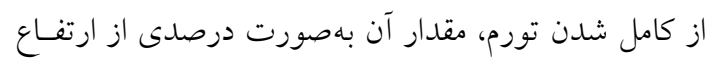

\begin{tabular}{|c|c|}
\hline 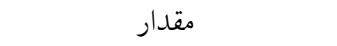 & مشخصات \\
\hline $\begin{array}{l}\text { rMrHT:dimethyl, } \\
\text { dehydrogenated tallow, } \\
\text { quaternary ammonium }\end{array}$ & اصلاح كننده آلى \\
\hline ITO & $\begin{array}{c}\text { غلظت اصلاح كننده } \\
\text { (meq/l。g) }\end{array}$ \\
\hline$\%<r$ & ر تربت \\
\hline$\%$ & افت وزنى \\
\hline $1 / 99$ & 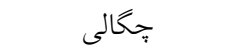 \\
\hline سفيد & رنخ \\
\hline$V Q_{0}$ & سطح ويزه( mº \\
\hline 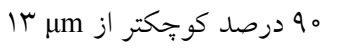 & اندازه ذرات \\
\hline
\end{tabular}

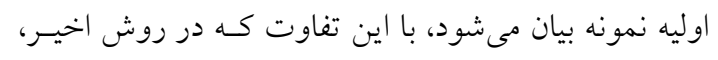

جدول ا. مشخصات نانورس مورد استفاده

ير اكتور استاندارد طبـق اسـتاندارد ASTM D991 روش اصـلاح شده طبق استاندارد STM D IOQV انجام شده است. خاكهاى رسى مورد بررسى جهت شناسايى دقيق تر و تعيسين

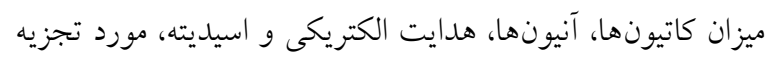

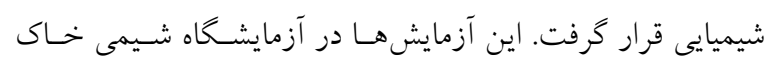
موسسه تحقيقات فنى و مهندسى كثاورزى انجام كرفت.

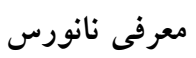

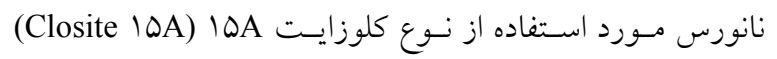

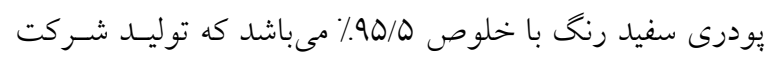

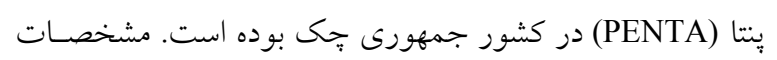

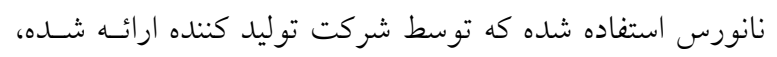
در جدول (1) نشان داده شده است.

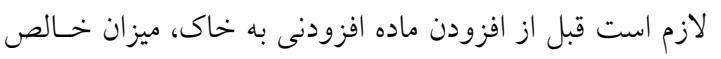

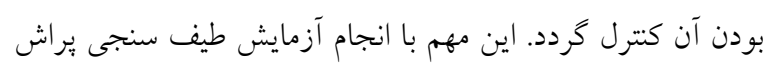

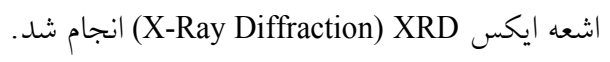

\section{طيف سنجى براش اشعه ايكس (XRD)}

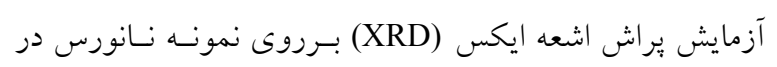

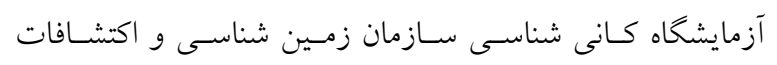

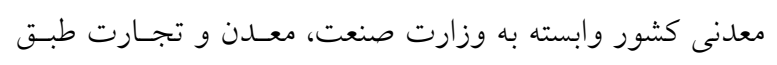




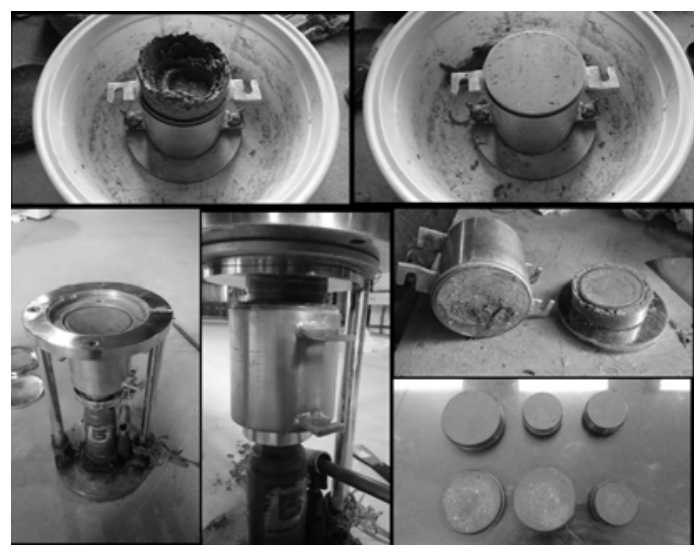

شكل 1. مراحل آماده سازى نمونه آزمايش تعيين بتانسيل تورم

برابر انرزى اسـتاندارد براكتـور بـوده و داراى دانسـيته خشـى ماكزيمم و بِتانسيل تورمى زيادترى نيـز اسـت، سـاخته شــنـد.

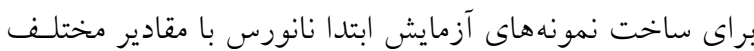

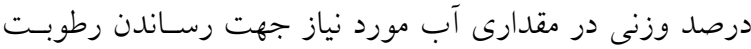

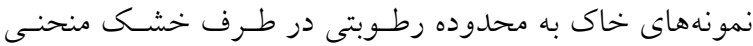
رطوبت، مخلوط و به حدى همزده شد تـا مخلموط يكنـواختى آنى

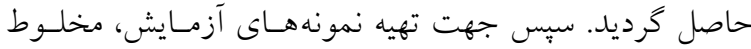
آب و نانورس به نمونههاى خاك اضافه شد. بهمنظور بررسى ترى

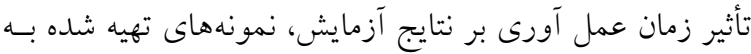
مدت ب و م ا روز در كيسه بِاستيكى در دماى آزمايشكاه عمل

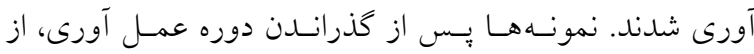

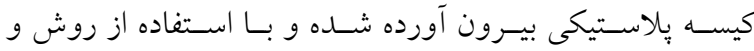
تجهيزات استاندارد ASTM D D ODVV متراكم شد. سبس از نمونسه

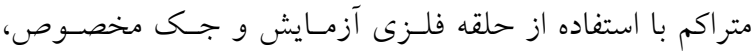

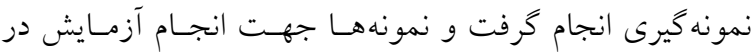
دستخاه تحكيم يكى بعدى قـرار داده شـــ مراحـل تهيـه نمونـهـ

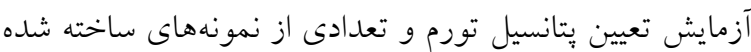
در شكل (1) نشان داده شده است.

\section{روش انجام آزمايش} حلقه آزمايش همراه با نمونه داراى سطح فرو رفس رفتـه، كاغـذهاى صافى (در صورت لزوم) و سنخهاى متخلخل خشك شـده در

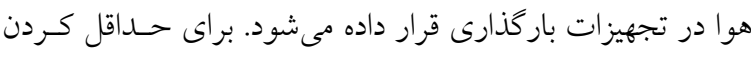

تورم نمونه تحت فشار سربار خاصى رخ داده است.

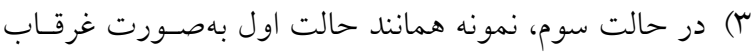

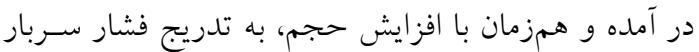

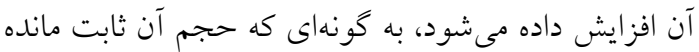

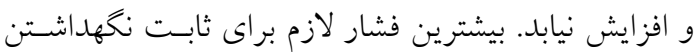
حجم نمونه و رساندن نسبت يوكى به نسبت يـوكى اوليـه،

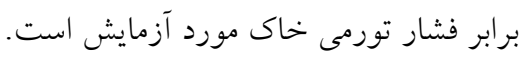

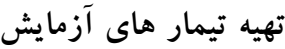

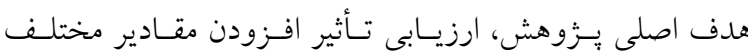

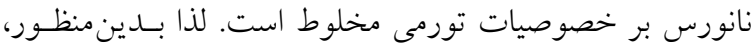
تيمارهاى آزمايش با در نظر كرفتن درصدهاى مختلف نـانورس آماده شد. جهت ساخت تيمارهاى آزمايش، ابتدا خاك رس كـهـ در محيط آزمايشكاه خشك شـده بـود، بـا جِكـش لاسـتيكى و هاون كوبيده شد و يس از عبسور دادن از الكى شـماره F F (ND

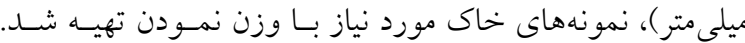
درصد وزنى بهصورت نسبت وزن نانورس به وزن خاك خشى

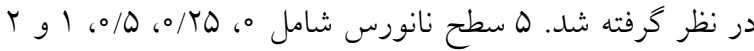
درصد وزنى در نظر گرفته شد. در نتيجه، ه نوع تيمار آزمايشسى

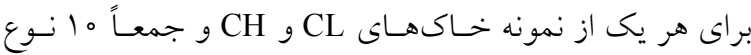
تيمار آزمايشى تهيه شد.

\section{روش آماده سازى نمونههاى آزمايش} در اين يزوهش براى انجام آزمايش تورم از نمونههاى بازسازى

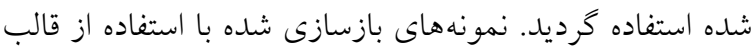

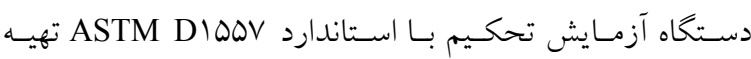

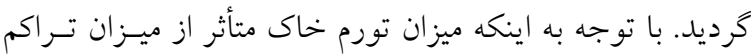

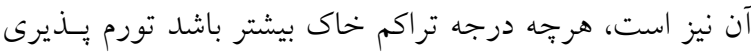

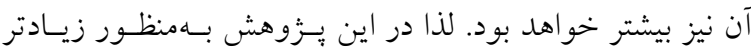
شدن بتانسـيل تـورمى نمونسهــاى مـورد بررسى و در نتيجـه

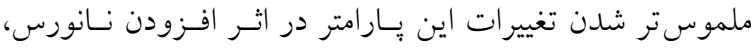

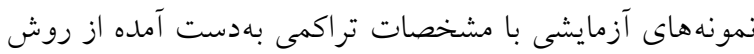

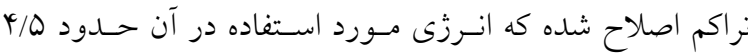




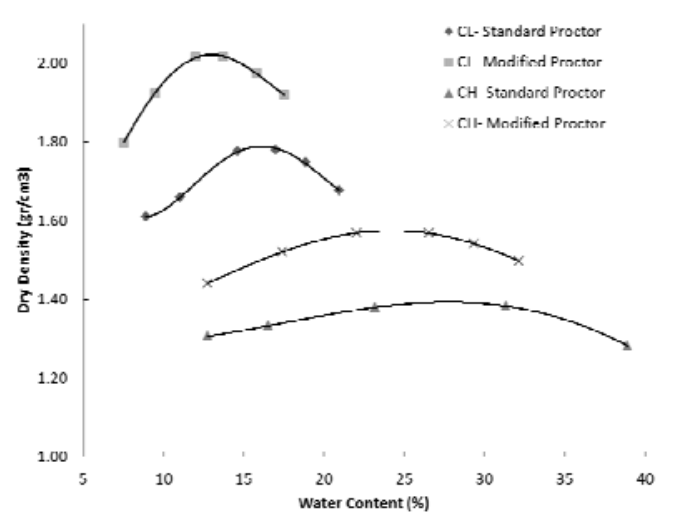

شكل r. منحنى تراكم يراكتور استاندارد نمونه خاكهاى CL و

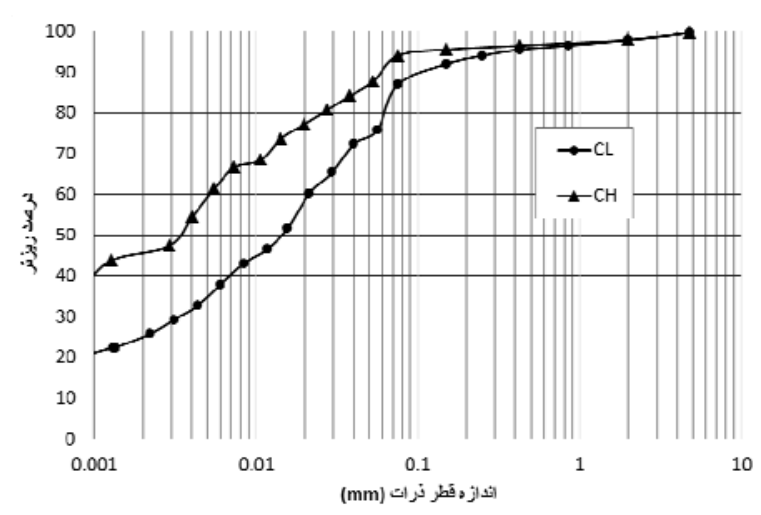

شكل Y. منحنى دانهبندى نمونه خاكهاى CL و CH

جدول r. مشخصات تراكمى نمونههاى مورد بررسى

\begin{tabular}{|c|c|c|c|c|}
\hline \multicolumn{2}{|c|}{ دانسيته خشك ماكزيمم (gr/cmr ) } & \multicolumn{2}{|c|}{ رطوبت بهينه (درصد) } & \multirow{2}{*}{ نمونه خاك } \\
\hline اصلاح شده & استاندارد & اصلاح شده & استاندارد & \\
\hline$r / l \circ$ & $1 / 79$ & $1 T / 0$ & 19 & رس منطقه ايو انكى (CL) \\
\hline $1 / 90$ & $1 / \pi$ & ro & rA & رس منطقه مغان(CH) \\
\hline
\end{tabular}

\section{نتايج و بحث}

آزمايش هاى شناسايي مطـابق بـا مـواردى كـه در قسـمت مــو اد و

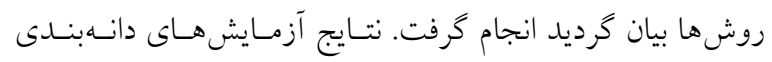
برروى نمونه خاكهاى CL و CH بهصورت منحنى دانسهنـدى در

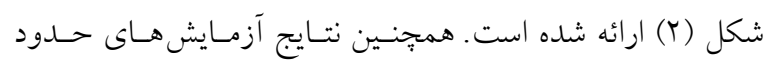

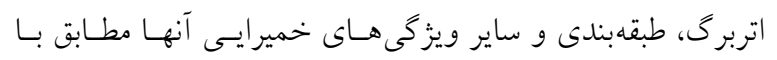

$$
\text { جدول (Y) است. }
$$

براساس نتايج آزمايش دانهبندى و حدود اتربرگ، طبقهبندى

نمونه خاكهاى مورد مطالعه منطقه ايوانكى و مغان طبق سيستم طبقهبندى متحد به ترتيب در رده رس با خاصيت خميسرى كـم و رس با خاصيت خميرى زياد (CL) آزمايشهاى تراكم بهروش يراكتور استاندارد و اصلاح شده كـهـ برروى دو نمونه خاك CL و CH انجام كرفـت، منحنسى تـــاكم بهدست آمده از اين آزمايشهـا در شـكل (r) نشـان داده شــده

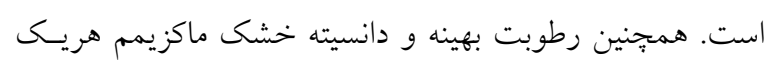
از نمونه ها به تفكيك آزمايش هاى براكتور اسـتاندارد و اصـلاح

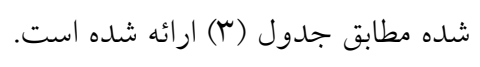

تغييرات رطوبت و حجم نمونه به علت تبخير، تجهيزات ياد شــه

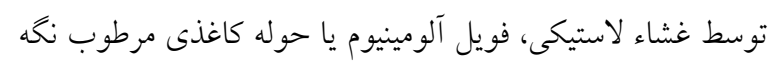

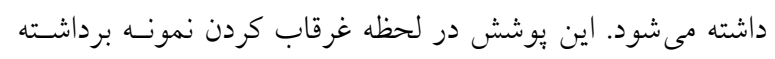

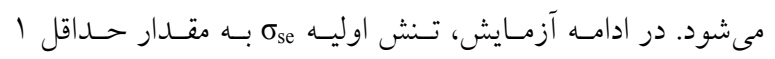
كيلوياسكال اعمال مى شود. در مدت زمان ها دقيقه بـس از اعمـال بار، كيج تغيير مكان قائم براى قرائت صفر تنظيم مىشود. يسس از قرائت صفر متناظر با تنش اوليه، نمونه غرقاب شده و تغيير شـكل آن در زمانهاى مختلف قرائت مىشود. قرائت در زمانهـاى / /ه،

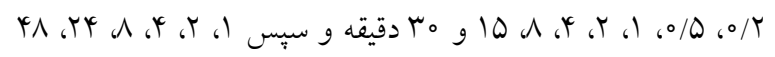
و VY ساعت مناسب است. قرائتهــا تـا بِيــان تـورم اوليـه ادامــه مىيابد. يس از يايان تورم، تنشهاى قائمى به مقدار تقريبى ه، ه 1،

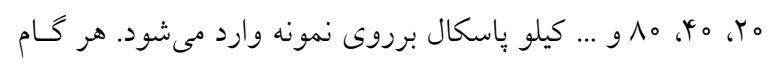
بار كذارى مشابه با آزمايش تحكيم برروى نمونه اعمال خواهد شد.

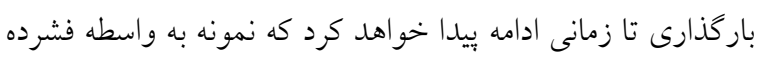

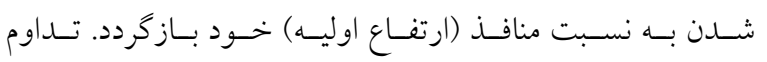

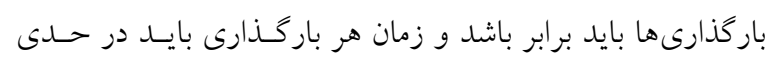
باشد كه ه 1\% تحكيم اوليه ايجاد شود. 


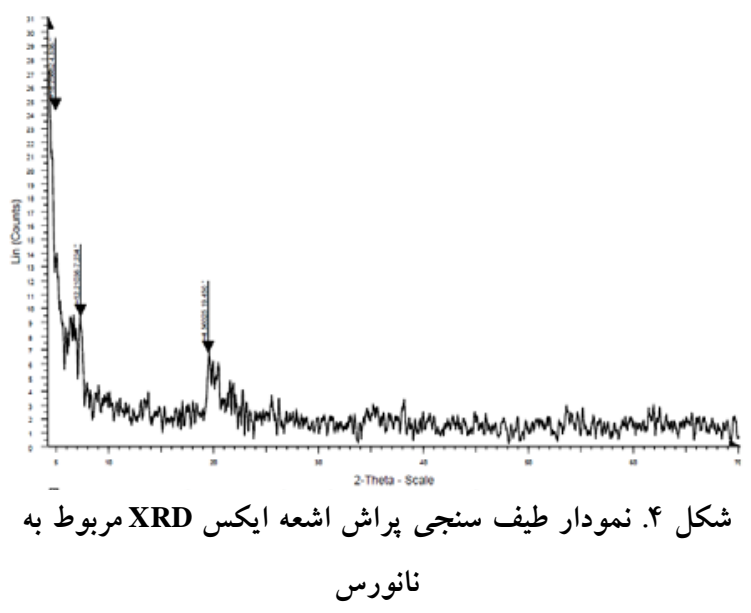

\begin{tabular}{|c|c|c|}
\hline $\mathrm{CH}$ & $\mathrm{CL}$ & مشخصه \\
\hline $\mathrm{V} / 9 \Lambda$ & V/VT & $\mathrm{pH}$ \\
\hline $\mid T / \circ \Lambda$ & $\vee / \wedge \Delta$ & $\mathrm{EC}(\mathrm{dS} / \mathrm{m})$ \\
\hline 10 & & (meq/lit) $\mathrm{Ca}^{\mathrm{r}_{+}}$ \\
\hline$G / T \Delta$ & $1 / / V 0$ & (meq/lit) $\mathrm{Mg}^{r+}$ \\
\hline $19 / 90$ & $r \Delta / 9 D$ & (meq/lit) $\mathrm{Na}^{+}$ \\
\hline $19 / T 0$ & 0 & (meq/lit) $\mathrm{HCo}_{r}{ }^{-}$ \\
\hline$r / \Delta$ & $19 / T 0$ & (meq/lit) $\mathrm{CL}^{-}$ \\
\hline$K \psi / V Q$ & Tr/T & $(\mathrm{meq} / \mathrm{lit}) \mathrm{So}_{4}{ }^{\mathrm{r}-}$ \\
\hline
\end{tabular}

جدول ه. درصد تورم نمونه خاك CL با تغيير نانورس و عمل آورى لم روزه

\begin{tabular}{|c|c|c|c|}
\hline رطوبت & دانسيته خشك (gr/cm & درصد تورم & درصد نانورس \\
\hline $1 \% / 9$ & $Y / 0$ & $N / \Delta Q$ & $\circ$ \\
\hline IT/V & $1 / 9$ & $0 / 90$ & $\circ / T \Delta$ \\
\hline 每 & $1 / 9$ & $4 / 90$ & $\circ / 0$ \\
\hline $1 T / K$ & $Y / 0$ & $\psi / \mu 。$ & 1 \\
\hline$I T / V$ & $1 / 9$ & $r / 90$ & r \\
\hline
\end{tabular}

جدول \&. درصد تورم نمونه خاك CL با تغيير نانورس و عمل آورى •ا روزه

\begin{tabular}{|c|c|c|c|}
\hline رطوبت & دانسيته خشك (gr/cm & درصد تورم & درصد نانورس \\
\hline $1 \% / 1$ & $T / l$ & $9 / r \mu$ & 。 \\
\hline $11 / 9$ & $1 / 9$ & $9 / 4 \circ$ & $\circ / T \Delta$ \\
\hline $\mid r / 4$ & $Y / \circ$ & $Q / 1 \circ$ & $\circ / 0$ \\
\hline $11 / 4$ & $1 / 9$ & $Q / \wedge 。$ & 1 \\
\hline $11 / 9$ & $Y / 0$ & $\Delta / \sim_{\Lambda}$ & $r$ \\
\hline
\end{tabular}

خالص بــودن نـانورس در حسدود خلـوص ارائسه شـده توسط شركت سازنده را نشان ميدهد.

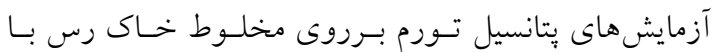

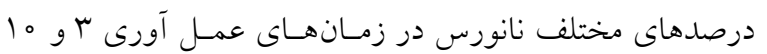

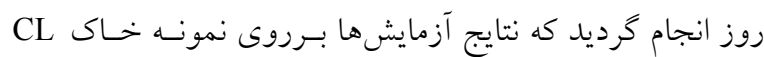
مطابق جداول (ه) و (9) و شكل (ه) مىباشد. با توجه به نتايج نشان داده شده در جداول ملاحظه مى گردد كه بهطور كلسى بـا افزايش درصد نانورس، درصد تورم خاك كاهش يافته است. بـا توجه به اينكه تغيير رطوبـت نمونـههــا در هنخـام آزمـايش بـر درصد تورم آن تأثير قابل توجهى دارد و همجنين يكسان نمودن
نتايج مربوط به آزمايشهاى تجزيه شيميايى برروى نمونسههـاى خـاى CL و CH در جـدول (Y) نشـان داده شـده اسـت. طبـق طبقهبندىهاى ارائه شده جهت قضاوت در مورد ميـزان شـورى خاى براساس مقدار هدايت الكتريكى عصاره اشـباع، مسىتـوان بيان نمود كه نمونه خاك CL در رده شورى كم و نمونه خـاى در رده شورى متوسط قرار داشته اند. نتيجه طيف سنجى براش اشعه ايكـس (XRD) كـه بـرروى

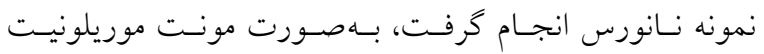
كزارش شد. در شكل (t) نمودار طيف سنجى نشـان داده شـده است. نتيجه مشاهده شـده از نمـودار XRD بـهـــور مشخصى 


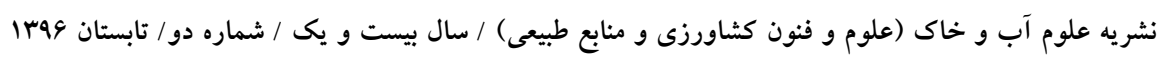
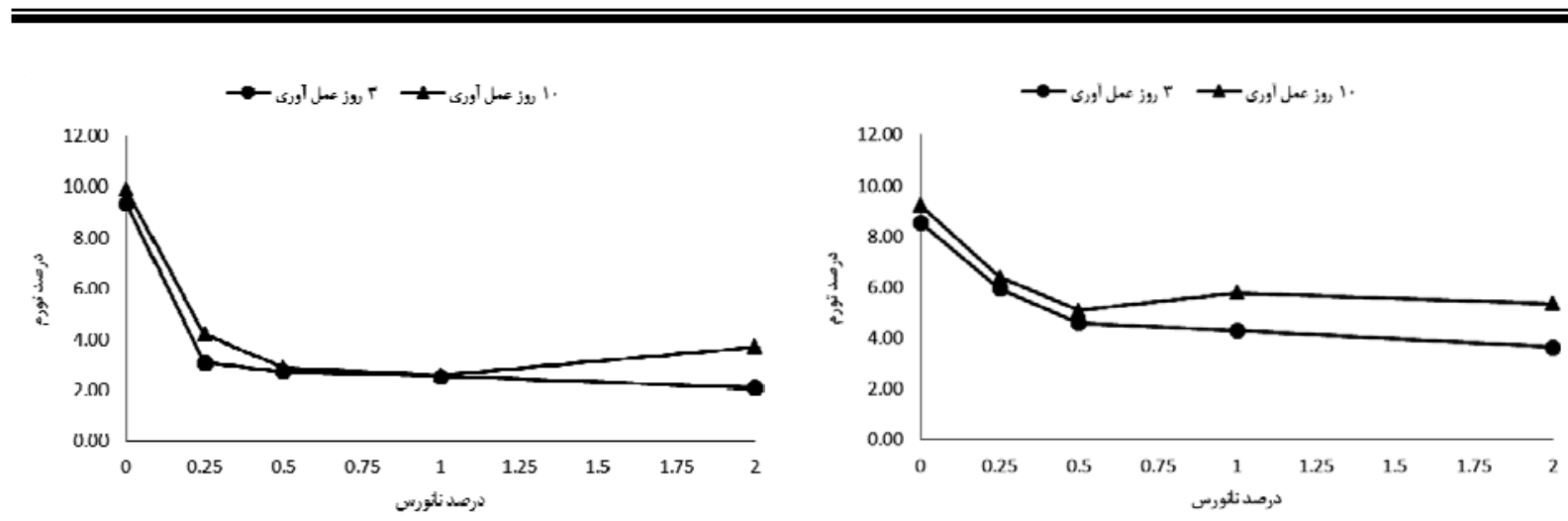

شكل 9. نمودار تأثير درصد نانورس بر درصد تورم نمونه خاك

شكل ه. نمودار تأثير درصد نانورس بر درصد تورم نمونه خاكناك

\begin{tabular}{|c|c|c|c|}
\hline رطوبت & دانسيته خشك (gr/cm & درصد تورم & درصد نانورس \\
\hline$T Y / 0$ & $1 / 9$ & $9 / 1 \%$ & $\circ$ \\
\hline$r Y / q$ & $1 / 9$ & $r / \circ \Lambda$ & $\circ / Y Q$ \\
\hline KY/V & $1 / 9$ & $T / N$ & $\circ / 0$ \\
\hline$Y Y / Y$ & $1 / 9$ & r/Or & 1 \\
\hline$Y Y / T$ & $1 / 9$ & $r / \circ \wedge$ & r \\
\hline
\end{tabular}

\begin{tabular}{|c|c|c|c|}
\hline رطوبت & دانسيته خشك (gr/cmr) & درصد تورم & درصد نانورس \\
\hline$r \mu / \mu$ & $1 / 9$ & $9 / 19$ & $\circ$ \\
\hline$r M / 9$ & $1 / V$ & $\varphi / r_{0}$ & $\circ / T Q$ \\
\hline rM/A & $1 / V$ & T/AV & $\circ / 0$ \\
\hline TY & $1 / 9$ & $r / \Delta \Lambda$ & 1 \\
\hline Tr/Q & $1 / 9$ & $r / v 。$ & r \\
\hline
\end{tabular}

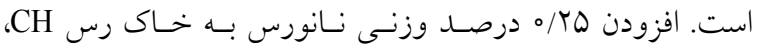
درصد تورم را در حدود 9V\% كاهش داده است. نكته ديخر كـه از

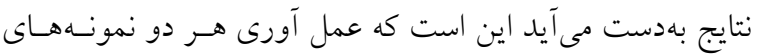
خاى CL و CH، تأثير قابل ملاحظهاى در كـاهش مقــار درصــ

$$
\text { تورم نداشته است. }
$$

تأثير افزودن نـانورس بــرورى فشـار تـورم براسـاس نتـايج

آزمايش هاى يتانسيل تورم براى دو نمونه خـاك رس CL و CH در شكلهاى (V) و (N) نشان داده شده است. مطـابق نتـايج در نمونه خاك CL افزودن نانورس و عمـل آورى ب روزه موجـب

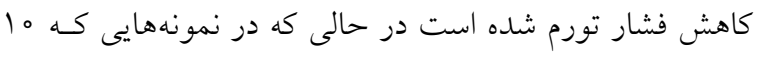
روز عمـل آورى شــده انـد، افـزايش درصسـ نـانورس موجــبـ افزايش فشار تـورم شـده اسـت. در نمونـه خـاك CH افـزودن
رطوبت نمونهها بهطور دقيقاً يكسان غير ممكـن مسىباشــ. لـذا اندكى افزايش درصد تورم در نمونسههـاى ها روز عمـل آورى شده را مىتوان به علت كم بودن رطوبت آن نمونه دانست. نتايج آزمايشهاى يتانسـيل تـورم بـرروى نمونسه خـاك CH مطابق جداول (V) و (N) و شكل (S) مى باشد. طبق نتـايج نشـان داده شده در جداول (V) و (N) و شكل (Y) بهطور كلى افـزودن نانورس به خاى رس CH نيز با كاهش درصد تـورم همـراه بـوده است. بيشترين تأثير كاهشى در ها؟ و ه/ه درصد وزنى نانورس رخ داده است و در درصدهاى بالاتر روند كاهش درصد تورم بـا شيب ملايم بيش رفته است. در اينجـا نيـز متـذكر مسى گـردد كـهـ افزايش اندك درصد تورم در r درصد وزنى نانورس به علت اين مى باشد كه نمونه مـــكور كمتـرين درصــ رطوبـت را دارا بـوده 


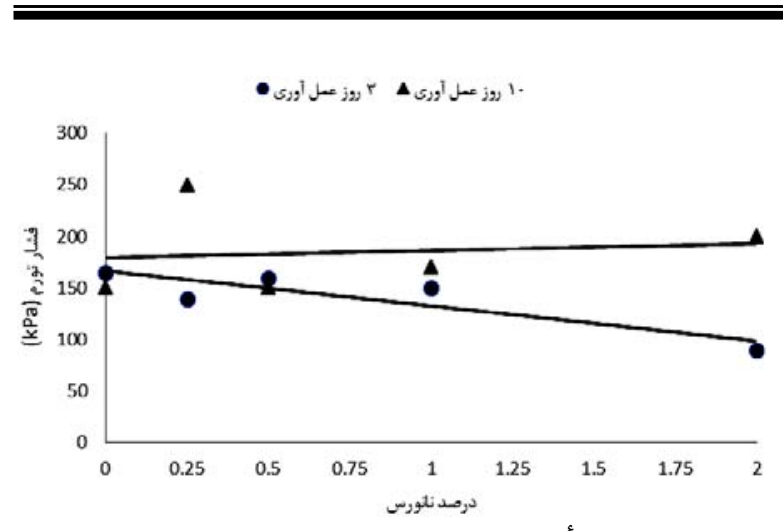

شكل ^. نمودار تأثير درصد نانورس بر فشار تورم نمونه خاك CH

مى يابد. اين عوامل نهايتاً باعث كاهش ضـخامت لايسه دو كانـه يخشيده و در نتيجه كاهش يُانسيل تورمى خاك مى گردد.

\section{نتيجه گيرى}

در اين يزوهش تأثير افزودن نانورس بر خصوصيات تـورمى دو

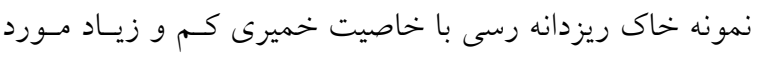

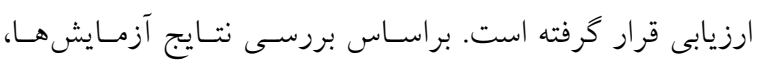

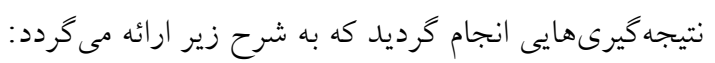

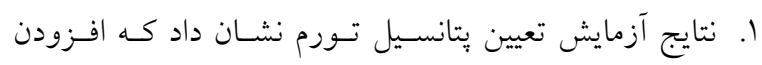

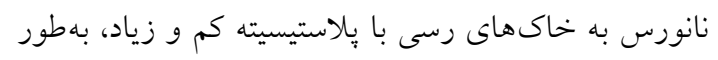
كلى موجب كاهش درصد تورم خاك مسى شـود. بيشـترين

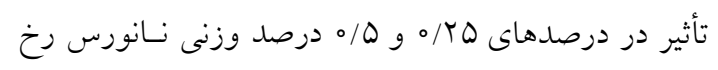

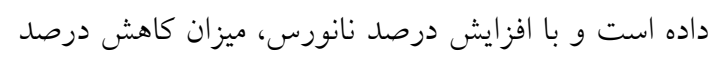

$$
\text { تورم كمتر مىشود. }
$$

r. مدات زمان عمل آورى نمونهها، تأثير قابل توجهى در نتسيج

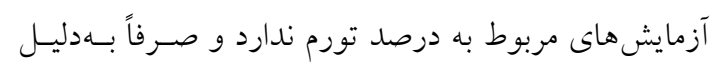

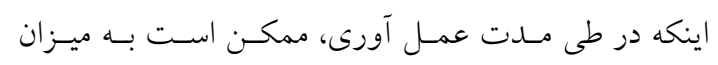

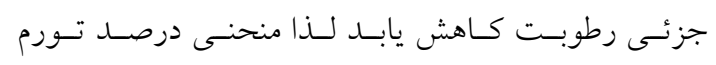

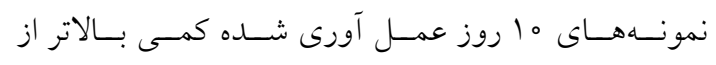

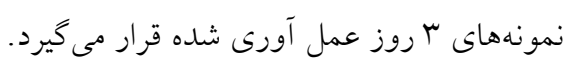

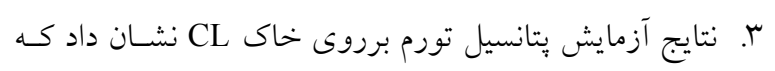

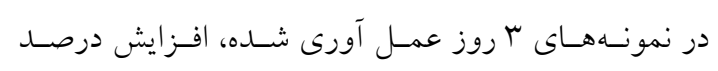

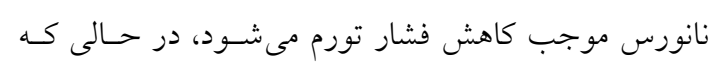

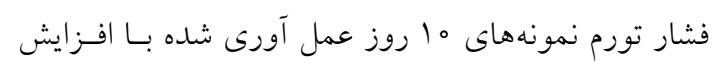

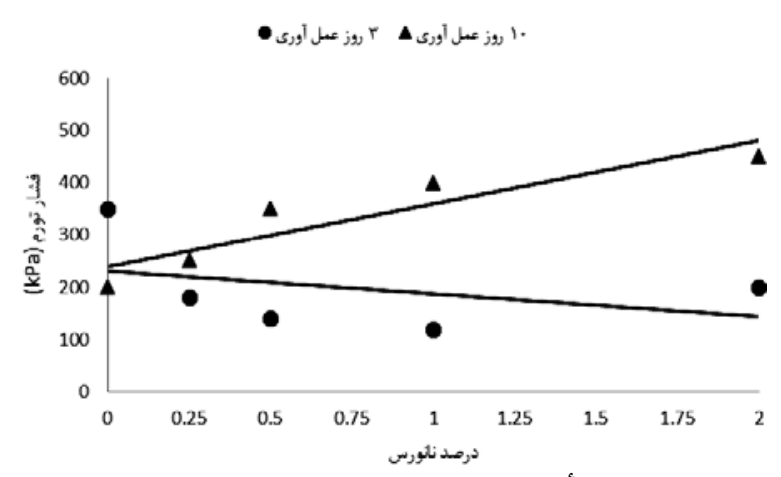

شكل V. نمودار تأثير درصد نانورس بر فشار تورم نمونه خاك CL

نانورس و عمل آورى ؟ روزه موجب كاهش فشـار تـورم شـده

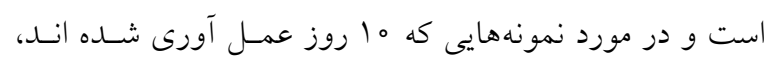
افزايش درصد نانورس تأثير جندانى بر فشار تورم نداثته است.

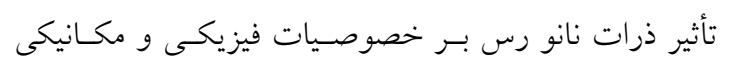

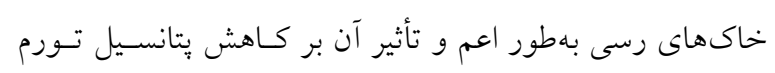

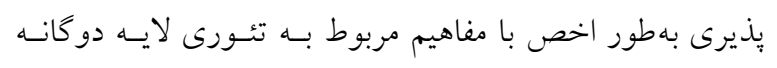

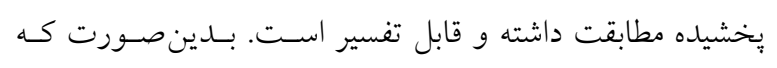

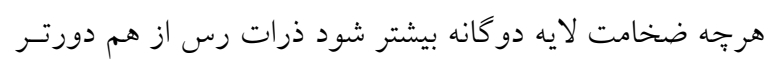

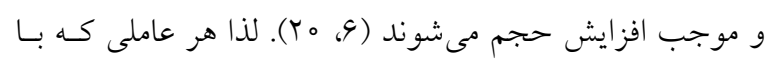

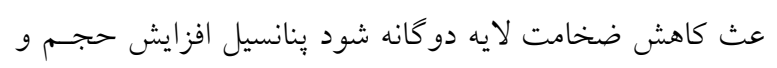

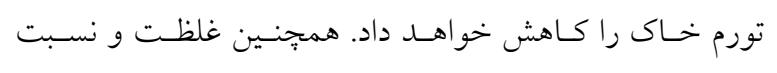

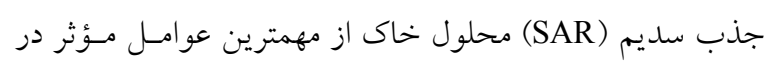

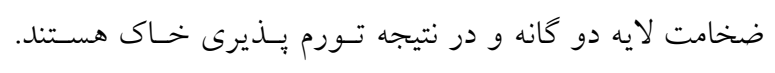

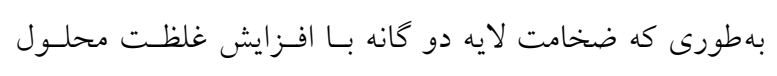

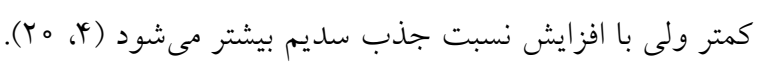

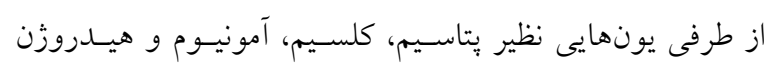

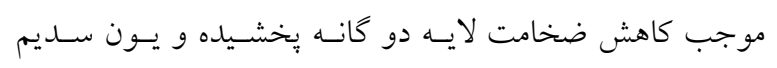
بهدليل شعاع هيدراته بيشتر موجب افزايش آن مسى شــوند (10).

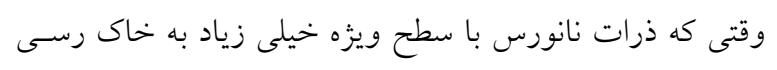

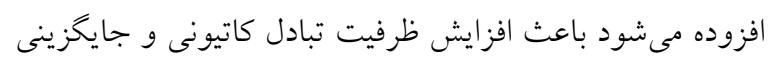

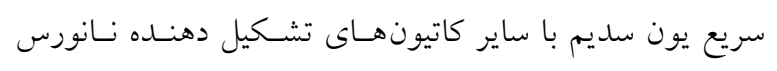

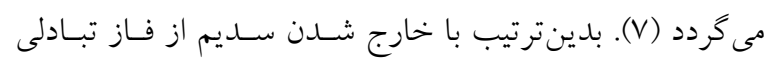

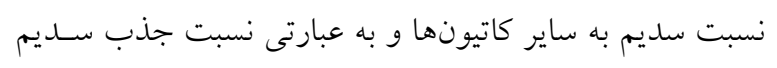

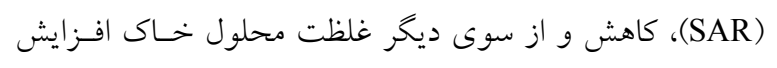




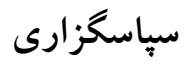

بدينوسيله نويسند كان اين مقاله از مديريت و كاركنان موسسـه

تحقيقات فنى و مهندسى كشـاورزى جهـت مسـاعدت و ارائسه

امكانات مورد نياز براى انجام يزوهش، قدردانى و سِّاسـخزارى

مى نمايند.
درصد نانورس، افزايش يافته است. همجنين مطسابق نتسايج

آزمايش يتانسيل تورم برروى خاك CH مشخص كرديد كه

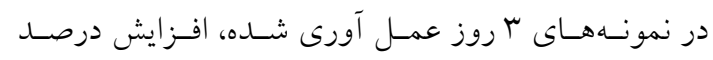

نانورس موجب كاهش فشار تورم مسىشـود، در حسالى كـه

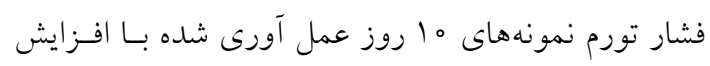

$$
\text { درصد نانورس، تغيير جناندانى نكرده است. }
$$

$$
\text { منابع مورد استفاده }
$$

3. Abbasi, N. 2011. The role of anions in dispersion potential of clayey soil. J. Agri. Eng. Res. 12(3) : 15-30.

4. Abbasi, N. and M. H. Nazifi. 2013. Assessment and modification of Shrard chemical method for evaluation of dispersion potential of soils. J. Geotech Geol. Eng. 31: 337-346.

5. Abbasi, N., A. Farjad and S. Sepehri .2017. The use of nanoclay particles for stabilization of dispersive clayey soils. J. Geotech Geol. Eng. 35: 1-9. doi.org/10.1007/s10706-017-0330-9

6. Hieu, P. and P. Quoc Nguyen. 2014. Effect of silica nanoparticles on clay swelling and aqueous stability of nanoparticle dispersions. J. Nanopart Res. 16(1): 2137. doi: 10.1007/s11051-013-2137-9

7. Huang, T. 2011.Clay Stabilization with Nanoparticles. Patent No. US 20110000672 A1. US 12/277,825

8. Kalkan, E. 2011. Impact of wetting-drying cycles on swelling behavior of clayey soils modified by silica fume. J. Appl. Clay Sci. 52: 345-352.

9. Majeed, Z. H. and M. R. Taha. 2012. Effect of nanomaterial treatment on geotechnical properties of a penang soil. J. Asian Scientific Res. 2: 587-592.

10. Majeed, Z. and M. Taha. 2013. A review of stabilization of soils by using Nanomaterial. Australian J. Basic and Appl. Sci. 7: 576-581

11. Majeed, Z. H., M. R. Taha and I. T. Jawad. 2014. Stabilization of soft soil using nanomaterials. Australian J. Basic and Appl. Sci. 8: 503-509.

12. Mohammadi, M. and M. Niazian. 2013. Investigation of nano-clay effect on geotechnical properties of Rasht clay. International J. of Advanced Sci. and Tech. Res. 3(3): 37-46.

13. Movahedan, M., N. Abbasi and M. Keramati. 2012. Wind erosion control of soils using polymeric materials. Eurasian J. of Soil Sci. 1(2): 81-86.

14. Movahedan, M., N. Abbasi and M. Keramati. 2011. Experimental investigation of polyvinyl acetate polymer application for wind erosion control of soils. J. of Water and soil (Agric. Sci. and Technol.) 25: 606-616

15. Neethu, S. V. and S. Remya. 2013. Engineering behaviour of nanoclays stabilized soil. In: Proceedings of Indian Geotechnical Conference. 22-24 December, India.

16. Ouhadi, V. R. and M. Amiri. 2011. Geo-environmental behavior of nanoclays in interaction with heavy metal contaminants. J. of Civil and Environ. Eng. 42(3): 29-36.

17. Rahimi H., N. Abbasi, H. Shantia. 2011. Application of geomembrane to control piping of sandy soil under concrete canal lining (case study: Moghan irrigation project, Iran). J. Irrig. Drain Eng. 60: 330-337. doi: 10.1002/ird.574

18. Rahimi H., N. Abbasi. 2007. Failure of Concrete Canal Lining on Fine Sandy Soils (A case study for Saveh Project). J. Irrig. Drain Eng. 57: 83-92. doi: 10.1002/ird.350

19. Rahimi, H. and S. H. Barootkoob. 2002. Concrete canal lining cracking in low to medium plastic soils. J. Irrig. Drain. Eng. 51: 141-153.

20. Sparks, Donald. 2000. Soil Physical Chemistry. CRC Press, Florida, 33431

21. Taha, M. R. and O. M. E. Taha. 2012. Influence of nano-material on the expansive and shrinkage soil behavior. J. Nanopart Res. 14: 1190. doi: 10.1007/s11051-012-1190-0 
استفاده از نانو ذرات رس براى تثبيت خاك هاى رسى متورم شونده

22. Yadu, L. and R. K. Tripathi. 2013. Effects of granulated blast furnace slag in the engineering behavior of stabilized soft soil. Procedia Eng. 51: 125-131.

23. Zhang, M, M. Zhao, G. Zhang, P. Nowak, A. Coen and M. Tao. 2015. Calcium-free geopolymer as a stabilizer for sulfate-rich soils. J. Appl. Clay Sci. 108: 199-207. 


\title{
Application of Nanoclay Particles for Stabilization of Expansive Clayey Soils
}

\author{
A. Farjad ${ }^{1}$ and N. Abbasi ${ }^{2 *}$
}

(Received: June 11-2016 ; Accepted: Oct. 01-2016)

\begin{abstract}
To deal with the destructive effects of swelling soils, different methods have been proposed by researchers. Chemical stabilization of expansive soils is one of the effective methods that are low-cost and efficient economically and technically. Recently, with the improvements of nano science in nanomaterials production and application, using this type of materials has been considered in different sciences especially geotechnical engineering. In this research, the effect of adding different amounts of nanoclay on swelling behavior modification of two types of clayey soils with low plasticity and high plasticity has been studied. For this purpose, first, identification tests were implemented on two types of clayey soils and nanoclay. Then, swelling potential tests were conducted on samples of soils with different amounts of nanoclay including $(0,0.25,0.5,1$ and 2 weight percent) considering curing ages of 3 and 10 days. The results showed that the effect of adding nanoclay to the high plastic soils swelling potential is more than adding it to that of low plastic soils. So, adding 0.25 to 0.5 weight percent of nanoclay reduces the swelling potential of high plastic soils about 67 percent, and that of low plastic solis about 3 percent. Furtheremore, the maximum reduction in swelling potential increases by adding up to 0.5 percent nanoclay; and decreases for adding amounts more than 0.5 percent.
\end{abstract}

Keywords: Swelling potential, Stabilization, Swelling pressure, Nanoclay.

1. Agricultural Engineering Research Institute, Agricultural Research, Education and Extension Organization (AREEO), Karaj, Iran

2. Dept. of Geotechnical Eng. College of Civil Eng. Central Branch of Islamic Azad University., Tehran, Iran.

*: Corresponding Author, Email: nader_iaeri@yahoo.com 